DOI: 10.2507/31st.daaam.proceedings.019

\title{
DROPSHIPPING DISTRIBUTION MODEL IN SuPPly Chain MANAGEMENT
}

\author{
Katarina Mostarac, Zvonko Kavran \& Josip Luka Pišković
}
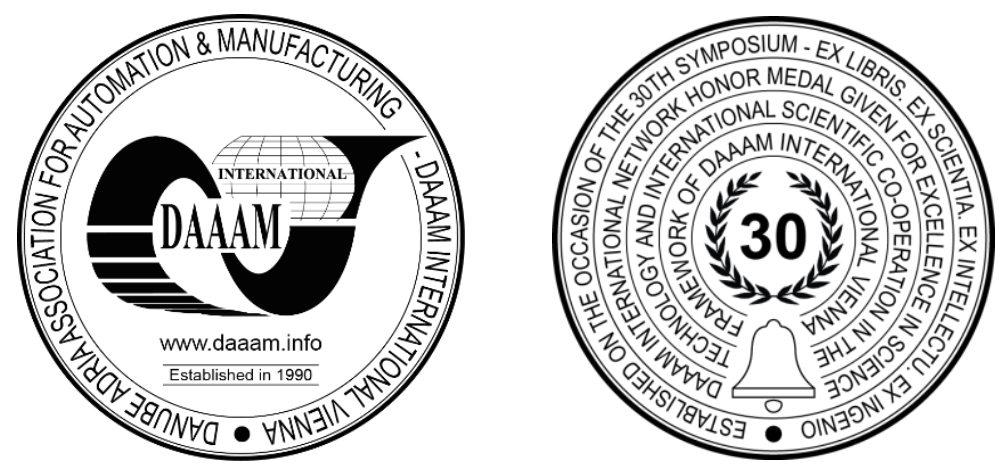

This Publication has to be referred as: Mostarac, K[atarina]; Kavran, Z[vonko] \& Piskovic, J[osip] L[uka] (2020). Dropshipping Distribution Model in Supply Chain Management, Proceedings of the 31st DAAAM International Symposium, pp.0144-0150, B. Katalinic (Ed.), Published by DAAAM International, ISBN 978-3-902734-29-7, ISSN 1726-9679, Vienna, Austria

DOI: $10.2507 / 31$ st.daaam.proceedings.019

\begin{abstract}
The dropshipping distribution model is relatively new method of distributing goods within the supply chain. This paper deals with the dropshipping distribution model, its implementation in logistics, and supply chain management. Growing trends in e-commerce are shown, and marketing methods, which are very important for setting up a business based on a dropshipping distribution model. A classic supply chain and supply chain operations based on a dropshipping distribution model are compared. Analysis of the advantages and disadvantages of both models will be presented, emphasizing the dropshipping distribution model future development.
\end{abstract}

Keywords: dropshipping distribution; supply chain management; e-commerce; social networks.

\section{Introduction}

\subsection{Classic supply chain}

The importance of supply chains is that it is the backbone of every industry [1]. With the advancement of globalization and digitalization, supply chains are facing an increased number of channels through which goods are transported and distributed. Generally, the supply chain consists of four primary phases (Figure 1) [2]:

- The procurement phase includes suppliers of raw materials, components, and raw materials

- The production phase includes manufacturers of final products

- The distribution phase includes wholesalers and retailers, logistics operators, carriers, and other entities that make the distribution network

- The consumption phase includes consumers (service users).

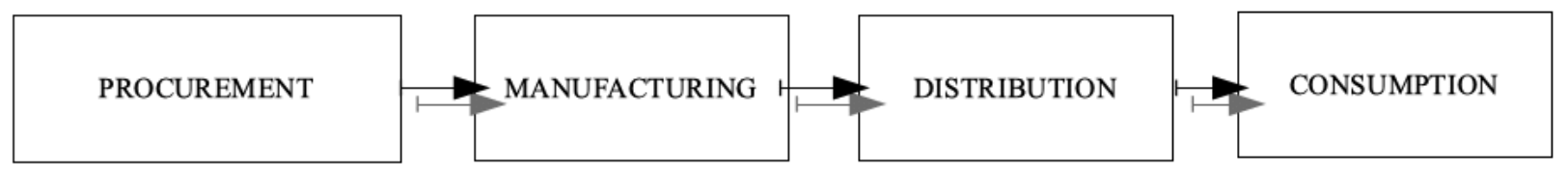

Fig. 1. Phases of supply chain 
The supply chain should be identified as a system that meets customer's needs with commercial profit (Figure 2). The supply chain system includes the interactions of the entities involved: customers, suppliers of raw materials, producers of final products, distributors (wholesalers), retailers, logistics operators, and carriers. These interactions are manifested in the flow of goods, exchange of information, and financial resources within stages of the supply chain [3].

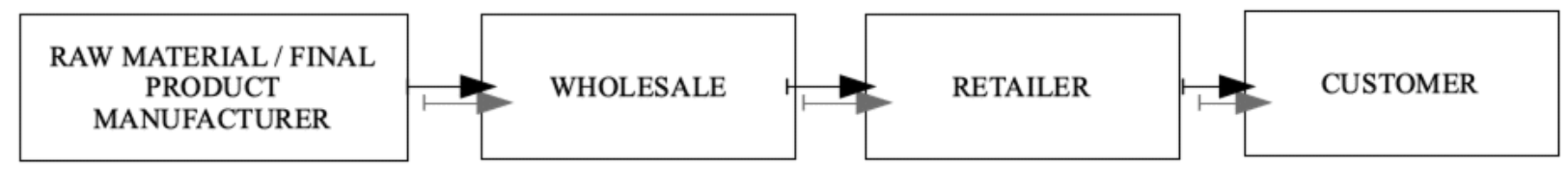

Fig. 2. Classic supply chain

\subsection{Dropshipping}

Supply chain management method in which the retailer does not keep the goods in stock, but instead transfers the customers' orders and delivery to the manufacturer or wholesaler is referred to as dropshipping. Dropshipping is a distribution/sale method in an alternative way to the classic supply chain. The whole process starts with the consumer who orders a specific product through the webshop. The webshop owner does not have products in its inventory but has an agreed dropshipping distribution channel with the supplier/manufacturer. When the webshop owner receives the order, it is forwarded to the supplier/manufacturer who fulfills the order in the warehouse and distributes it through logistics and courier services directly to the customer.

The application of e-commerce eliminates individual storage costs for all entities except manufacturers, while dropshipping reduces retail costs (storage, space rental costs, staff costs, and additional services such as the declaration, barcoding, etc). Given the existing trends, e-commerce represents an integral part of global trade, and the need for more significant consideration in supply chains arises.

Dropshipping includes manufacturer/supplier, logistics operators/courier services, web retailer, and consumer/customer. It starts with a consumer's search for a particular product that initiates a purchase through a webshop found through internet advertisements (Google Adwords, Google Adsense, Facebook, Instagram, etc) or through existing social networking sites (Facebook, Instagram). The consumer found a preferred product and placed the order with a web retailer. Web retailer has access to the manufacturer's inventory of a particular product, which is selling in real time. The web retailer then forwards the order to the manufacturer and pays for the product and delivery with a portion of the money paid to it by the consumer. Within five days, the manufacturer/supplier fulfils the order and sends it via logistics/courier operators to the end customer.

Dropshipping consists of a smaller number of entities than the classic supply chain because the classic retail is left out and replaced by online sales. The manufacturer and wholesaler are the same entity, where the classic wholesalers/agents are removed (Figure 3).

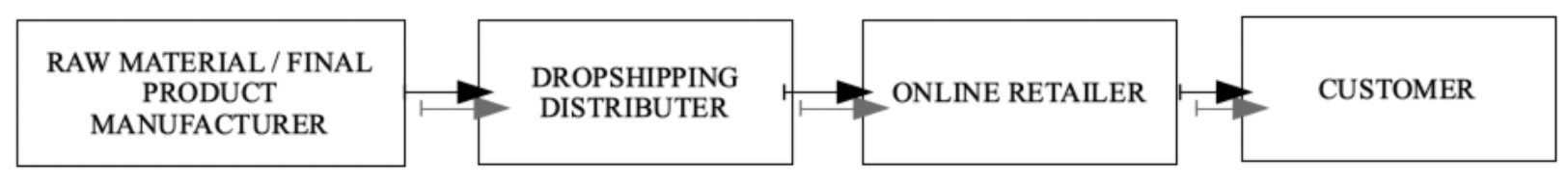

Fig. 3. Dropshipping distribution channel

The dropshipping reduces operating costs and provides a global service area through large logistics operators that have contracts with manufacturers that meet their business requirements. In a traditional supply chain, there may be an inability to meet extensive logistics /courier services' requirements. This is because some retailers do not meet the minimum amount of monthly deliveries and are therefore limited to the retail outlet's service area, and not the national/global market.

The following advantages of dropshipping can be identified:

- The cost of retail inventory is eliminated

- The retail costs (space rent, staff costs, electricity, water, cleaning costs) are eliminated

- Product service area is national/global

- Risks of non-current stocks are eliminated

- No need for large investments (unnecessary inventory, products are paid for from customers' money)

- Low business risk

- The growing popularity of social networks makes it possible to increase the trend of dropshipping

- Time-saving. 
However, some authors identify potential disadvantages of dropshipping [4]:

- Fragmentation of orders

- Retailer does not have control over the distribution of the products

- Possible lack of communication between parties in the dropshipping channels

Consequently, the possibilities and risks of dropshipping are shown in Table 1.

\begin{tabular}{|c|c|}
\hline Possibilities & Risks \\
\hline Mitigated investment costs & Fragmented orders \\
\hline Broader assortment & Loss of control \\
\hline Decreased transportation costs & Diminished product margins \\
\hline Avoided inventory costs & Not sufficient communication \\
\hline Increased product availability & Longer lead times \\
\hline $\begin{array}{c}\text { Decreased overall costs for e- } \\
\text { fulfilment }\end{array}$ & \\
\hline
\end{tabular}

Table 1. Possibilities and risks of dropshipping [4]

This research aims to compare the classical supply chain, and the supply chain where the dropshipping is applied. The aim of comparing the classic supply chain and dropshipping is to identify the differences, advantages, disadvantages and finally, costs generated by both. With the boost of e-commerce, it becomes necessary to study online marketing and social networks within supply chains.

\section{E-commerce and online marketing methods}

\subsection{Factors that influence e-commerce}

With the growth of broadband Internet subscribers, mobile phone users and social networks, e-commerce (often referred to as e-shopping) has increased its overall global trade share. Critical factors that influence the development and implementation of online shopping are shown in Figure 4.

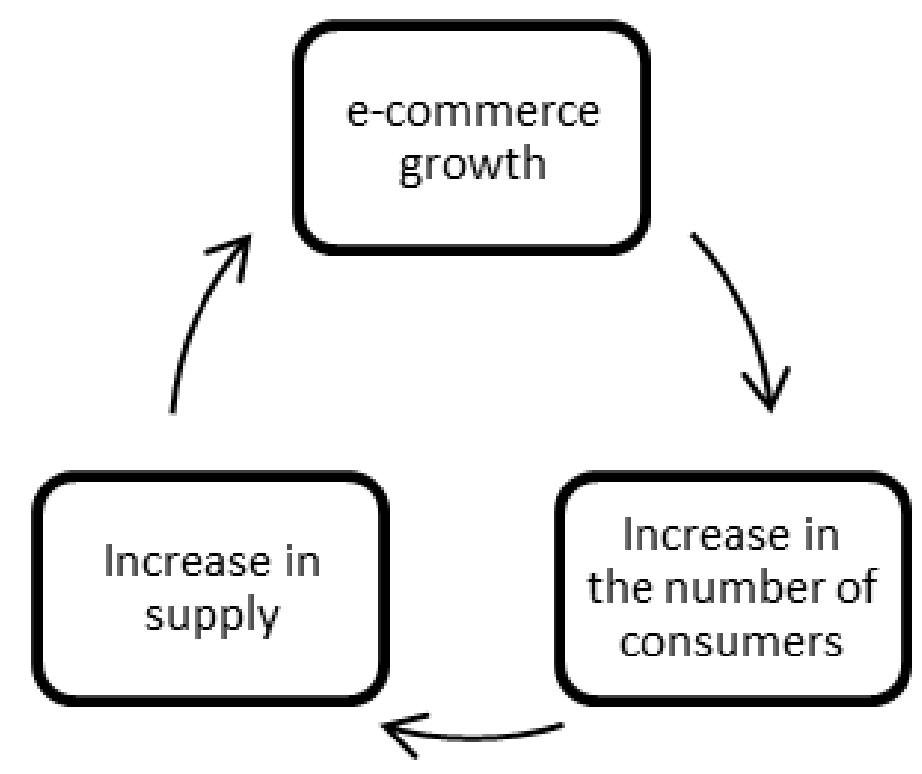

Fig. 4. Key factors for e-commerce growth [5]

According to Eurostat, definition of e-commerce, is purchase of goods or services (between businesses, households, individuals or private organizations), through electronic transactions via the Internet or online communication networks [6]. The number of active paying e-commerce customers is continuously increasing (Figure 5), and it is predicted to (almost) double in 2024 (compared to 2017 results). 


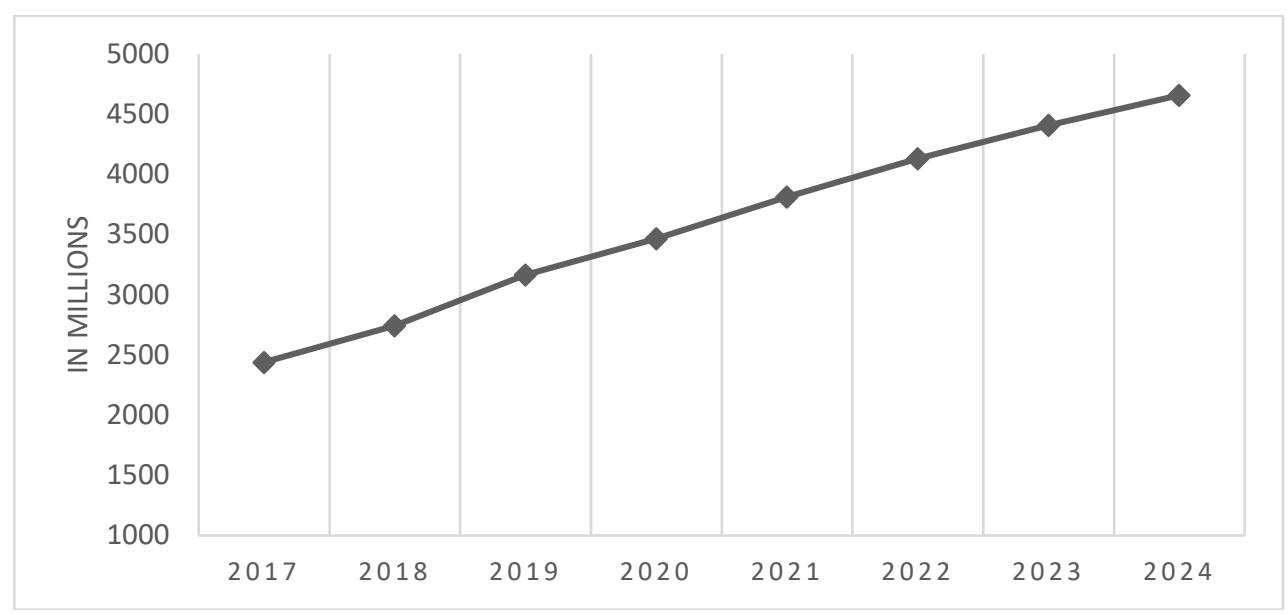

Fig. 5. Number of e-commerce users (active paying customers) [7]

According to E-Commerce Europe [8], the share of consumers who shopped online in the European Union varies. Western Europe and Scandinavian countries have the highest share of online shopping consumers (all over $80 \%$ and higher), where Switzerland is best positioned with $88 \%$ of people who shopped online. Eastern European countries (Ukraine, North Macedonia, Bulgaria) have the lowest share of online shopping consumers, while Croatia is at the back of the rank with a modest $47 \%$ online shopping consumers.

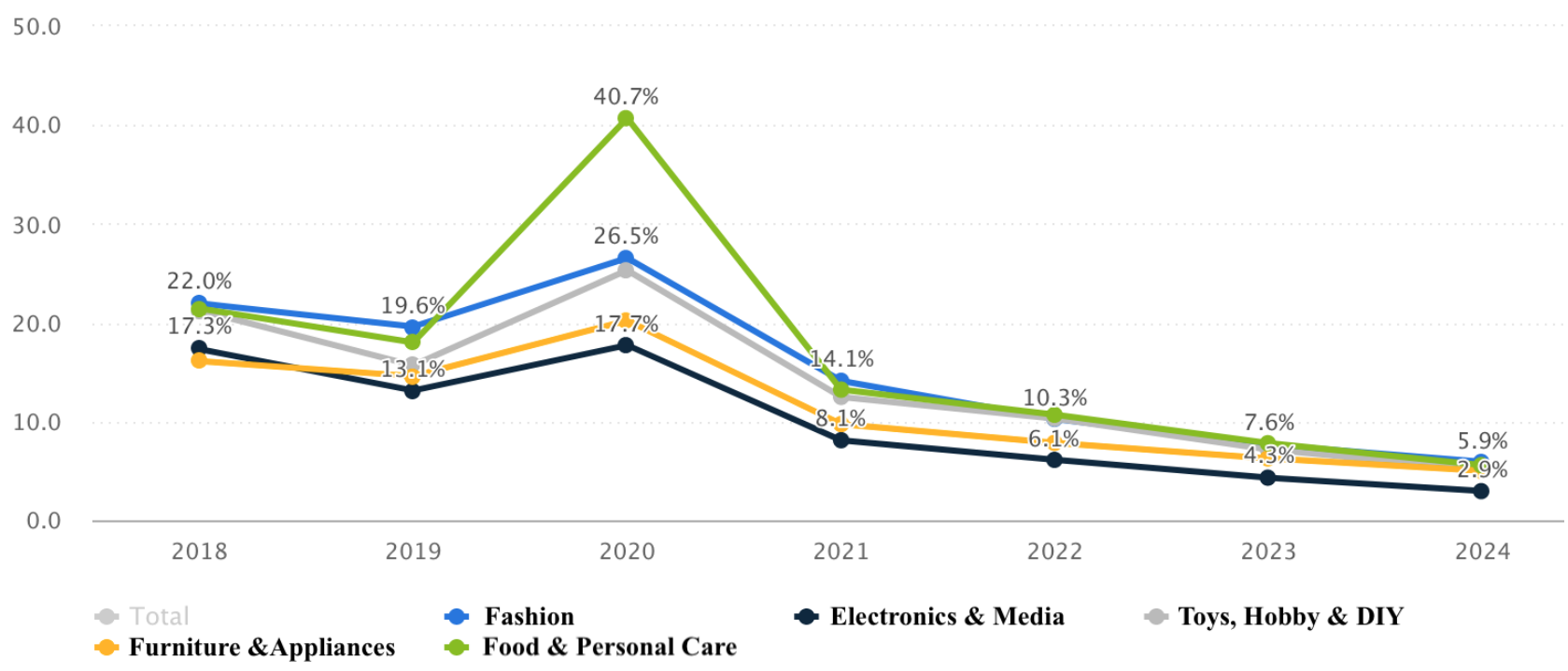

Fig. 6. E-commerce revenue growth [7]

Figure 6 shows revenue growth in the last two-year period (2018 - 2020), and prediction for the next four-year period $(2020$ - 2024). It is interesting to notice deviation when the year 2020 is observed. It is noticeable that food and personal care products generated over $40 \%$ of revenue growth. Toys, hobby and DIY products recorded about a $10 \%$ increase in the revenue growth in the same period. This is the direct consequence of the SARS COV 2 virus pandemics, where we witnessed a high share of online shopping compared to the previous period.

\subsection{Social networks as online marketing generators}

Internet marketing or online marketing refers to advertising various activities, services and products via the Internet, using modern methods. New media is evolving and changing extremely fast, so this type of marketing requires continuous adaptation to new technologies, and trends [9].

Massive advantage of online marketing is its affordable price. It allows exact targeting of a group of people, so the content of promotional messages is directed precisely to those who make up a group of potential consumers. This saves funds within the available advertising budget. In addition to promotional messages, informative content is important, as encourages two-way communication and feedback. The critical difference between the Internet and traditional media is precisely this component of interactivity. Creative approach to two-way communication results in satisfied consumers [9]. 
Social media (networks) are media for social interaction, and that has changed the way organizations and individuals communicate [10]. Social media (networks) allow exchanging ideas, content, thoughts, and interpersonal relationships over the Internet. Social media differs from traditional media so that anyone can make content on them. Social media include text, sound, video, image, and community of people. Social networks eliminate the need for intermediaries, the traditional media in communication with the groups of potential customers. Social networking is direct and targeted to key segments [10].

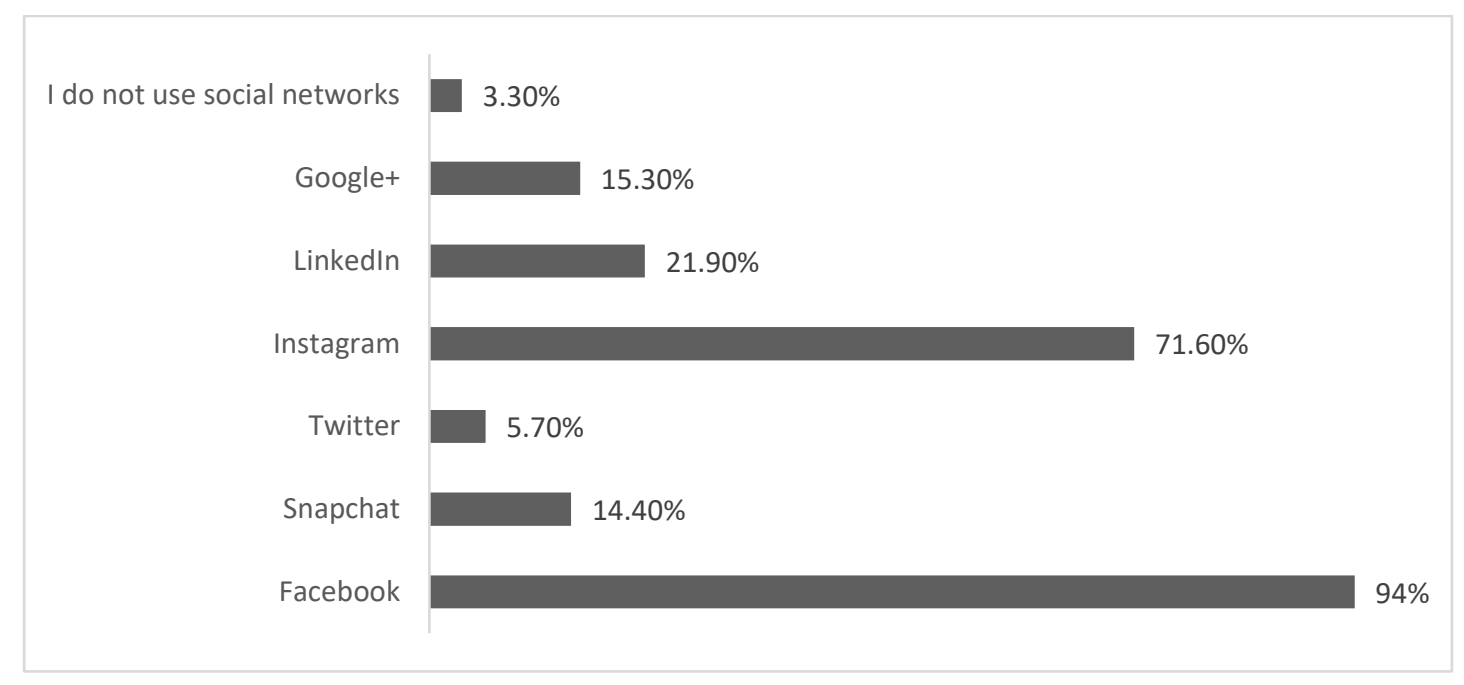

Fig. 7. Most commonly used social networks [10]

Figure 7 shows the common types of social networks used. Most of the respondents used social networks, preferably Facebook and Instagram. These platforms give excellent basis for the creation of marketing campaigns to focused groups of consumers.

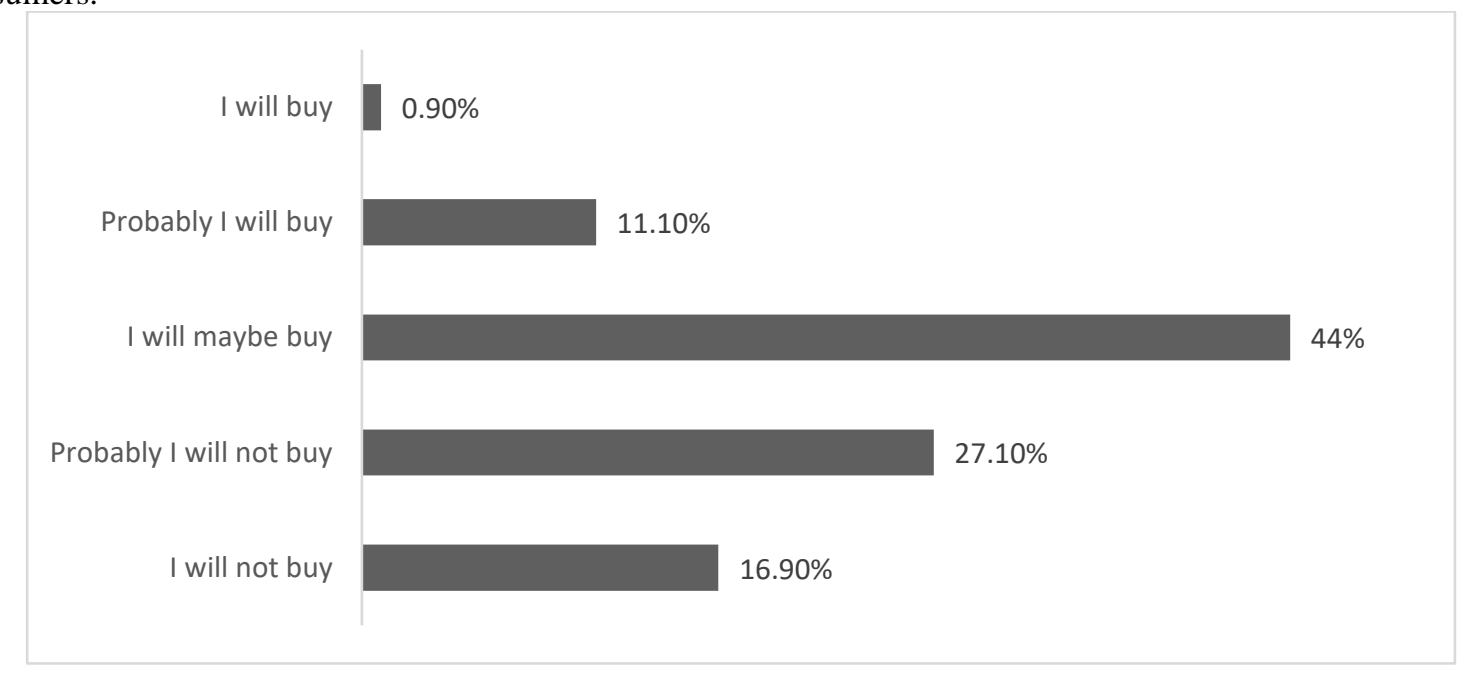

Fig. 8. Probability of buying a product sponsored on a social network [10]

When online marketing is concerned, it is interesting to analyse respondents' views on buying products advertised on social networks. Figure 8 shows the probability of buying a product that is advertised on a social network. More than half of the respondents will (maybe) probably buy products that are advertised via social networks. If the advertising strategy is aimed at a focused and targeted group of consumers, online marketing campaigns can be efficient in promotion and selling products.

\section{Comparison of the classic supply chain and dropshipping costs}

The classical supply chain and dropshipping distribution channel are compared and presented in Figure 9. Most of the differences between distribution channel modes are in the retail entity (classic retail outlet or online shop) and consequently, distribution. Distribution or the product's delivery is carried out by the retailer (in classical mode) or directly by the manufacturer or the supplier of the products (when dropshipping is concerned). 


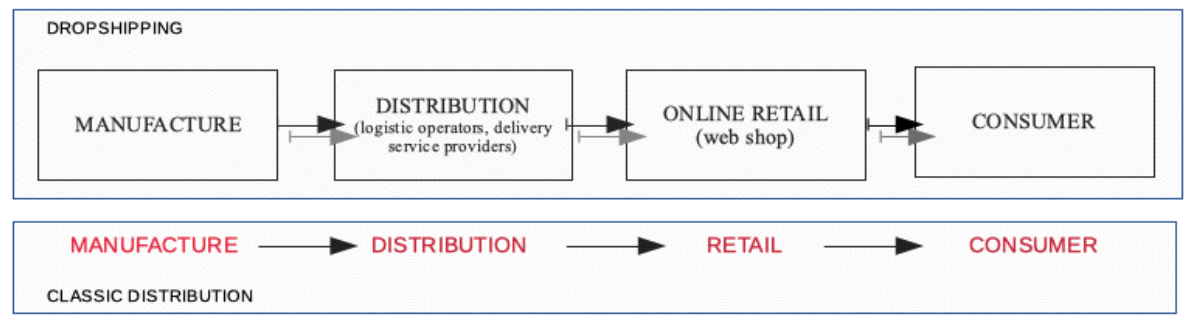

Fig. 9. Dropshipping vs. classical distribution channels

As mentioned before, the fragmentation of products can be identified as one of the most significant disadvantages of the dropshipping. It is generated by the distribution/delivery phase, where one consumer orders different products from different suppliers. This can affect the quality, speed, and transparency of the delivery. However, the delivery service providers can help eliminate this problem by integrating operations and introducing technical solutions that will help fragmentize orders. A comparison of supply chain and dropshipping is performed. We calculate the cost of a classic supply chain vs. dropshipping on an example of a shoe retailer. Classic method is based on a retail outlet located in the city of Zagreb. Coasts of the outlet are shown in Table 2. Cost and income are expressed in Croatian kuna (HRK) and are monthly based.

\begin{tabular}{|l|c|}
\hline Cost item & Cost [HRK] \\
\hline Total worker salary & 22000 \\
\hline Manager salary & 6000 \\
\hline Space rental & 3000 \\
\hline Cost of product stock & 12600 \\
\hline Utilities (electricity, water, waste) & 890 \\
\hline Web address cost & 35 \\
\hline The average accounting cost & 750 \\
\hline Total cost & 45275 \\
\hline Total income & 54000 \\
\hline Total profit & 8725 \\
\hline
\end{tabular}

Table 2. Classic retail outlet costs

Costs of dropshipping are calculated based on an online webshop specialized in shoe sale. Costs and income are calculated and presented in Table 3. Cost and income are expressed in Croatian kuna (HRK) and are monthly based.

\begin{tabular}{|l|c|}
\hline Cost item & Cost [HRK] \\
\hline Cost of Shopify web page & 185 \\
\hline The average cost of manufacturer/supplier product & 320 \\
\hline Average cost of delivery & 96 \\
\hline Instagram marketing & 800 \\
\hline Facebook marketing & 2880 \\
\hline Google Adwords & 960 \\
\hline The accounting cost & 750 \\
\hline Total cost & 16455 \\
\hline Total income & 24000 \\
\hline Total profit & 7545 \\
\hline
\end{tabular}

Table 3. Online retail costs

Comparing both channels of distribution, it is evident that classic retail outlet has almost three times higher costs that the webshop outlet. It also has higher income, but, in the end, difference between profit is not very significant. It is evident that the classic retailer has much higher risks than the online retailer. It also has a slightly higher profit. Also, a classic retailer has higher costs because the costs of utilities, space renting, staff etc. On the other hand, online retail does not have such costs because everything takes place online. The online retailer has a broader marketing strategy and attracts consumer from a wider geographical area, while the classic retail outlet is limited to its service area. If the sale is not satisfactory, the online retailer does not have high costs because the stocks are ordered according to the end consumer's needs. This can represent problems for the classic retailers because if all product stocks are not sold, total income is endangered. 


\section{Limitation of the study and future research}

This research is focused on the comparison of the traditional supply chain and the dropshipping model of distribution, using just the case study of the shoe sale in retail outlet and webshop scenario. Basic costs and income are taken into consideration when calculating overall profit for the two modes of the shoe sale. However, additional costs that may arise during time period (salary increase, change in utility and service costs, etc.) are not considered. Furthermore, costs of delivery can vary, depending on the delivery speed, distance, return policies etc. In the end, this can also significantly influence the costs and overall profit. Considering a large number of people using social networks and the impact they have on the consumers' shopping habits and preferences; future research should focus on this aspect. Determining the exact influence of particular social network and advertising platforms on e-commerce could help the supply chain management and planning of logistics processes.

Furthermore, analysis of the various categories of products should also be the focus of research. Different kinds of products generate different costs. Comparing logistical processes when different products are taken into consideration would also give valuable insight into supply chain management.

\section{Conclusion}

The dropshipping model of the supply chain has advantages compared to classic retail of high operating costs and high risk. The traditional retailer is less competitive to online retail in term of advertising to a wider focused audience. Internet use in selling goods and services is gaining significance because people make extensive use of social networks and spend a significant amount of time online. Social networks offer a high level of marketing because data are collected, and advertisement and marketing campaigns are based on people's preferences.

Comparing costs from a web retailer and a traditional retailer, it is evident that the traditional retailer has much higher risks and initial investments compared to the web retailer. It also has a slightly higher profit. Traditional retailers' initial costs are high due to the stock of products that are obtained before the start of sales and staff salaries. Web retailer can change marketing strategy that bears a large portion of the cost if the sales performance is not satisfactory. The traditional retailers have much higher costs of rent, staff, utilities, etc. while marketing is limited to mostly service areas.

\section{References}

[1] Madhwal, Y. \& Panfilov, P. (2017). Blockchain And Supply Chain Management: Aircrafts' Parts' Business Case, Proceedings of the 28th DAAAM International Symposium, pp.1051-1056, B. Katalinic (Ed.), Published by DAAAM International, ISBN 978-3-902734-11-2, ISSN 1726-9679, Vienna, Austria DOI: 10.2507/28th.daaam.proceedings. 146

[2] Planning of logistical processes 2), (Planiranje logističkih procesa 2) Available at: https://moodle.srce.hr/20172018/pluginfile.php/1486059/mod_resource/content/0/PLP_P_2.pdf Accessed on: 2020-07-01

[3] Planning of logistical processes 1, (Planiranje logističkih procesa 2) Available at: http://estudent.fpz.hr/predmeti/p/planiranje_logistickih_procesa/novosti/nastavni_materijali_1.pdf Accessed on: 2020-2006

[4] Haskel, F., Mulolli, L. (2017). The role of Drop Shipping in E-Commerce, Master's Degree Project in Logistics and Transport Management, School of Business, Economics and Law, University of Gothenburg, Gothenburg, Sweden.

[5] Butigan, I. (2019). Development of e-commerce and its impact on the economy of the Republic of Croatia, (Razvoj e-trgovine i njen utjecaj na gospodarstvo Hrvatske), Master's Thesis, Faculty of Economics, University of Split, Split, Croatia.

[6] https://ec.europa.eu/eurostat/statistics-explained/index.php/Glossary:E-commerce (2020). Accessed on: 2020-0901

[7] https://www.statista.com/outlook/243/100/ecommerce/worldwide Accessed on: 2020-09-02

[8] Ecommerce Europe. (2019). European E-commerce Report, Available at: https://www.ecommerce-europe.eu/

[9] https://www.virtualna-tvornica.com/internet-marketing-edukacija/ Accessed on: 2020-31-08

[10] Zeljko, D, Jakovic, B. \& Strugar, I. (2018). New Methods of Online Advertising: Social Media Influencers, Proceedings of the 29th DAAAM International Symposium, pp.0041-0050, B. Katalinic (Ed.), Published by DAAAM International, ISBN 978-3-902734-20-4, ISSN 1726-9679, Vienna, Austria DOI: 10.2507/29th.daaam.proceedings.006 